\title{
PERSEPSI PETANI PADI TERHADAP KEGIATAN PENYULUHAN PERTANIAN DI DESA SUKARAMI KELURAHAN TABA PENANJUNG KABUPATEN BENGKULU TENGAH
}

\section{RICE FARMER PERCEPTIONS OF AGRICULTURAL EXTENSION ACTIVITIES IN SUKARAMI VILLAGE BENGKULU TENGAH DISTRICT}

\author{
Mindo Marsaulina. $\mathbf{T}^{\mathbf{1}}$, Herlina $^{2}$, Yossie Yumiati ${ }^{3}$ \\ 1) Program Studi Agribisnis Fakultas Pertanian UNIVED \\ 2) Program Studi Agribisnis Fakultas Pertanian UNIVED \\ ${ }^{3)}$ Program Studi Agribisnis Fakultas Pertanian UNIVED
}

\begin{abstract}
ABSTRAK
Pembangunan pertanian merupakan bagian penting dan tidak terpisahkan dari pembangunan nasional. Hal ini terlihat dari Swasembada beras pada tahun 1982. Keberhasilan pembangunan pertanian tidak terlepas dari kegiatan penyuluhan pertanian sebagai inovasi sosial yang bertujuan untuk mengubah tingkah laku masyarakat (petani) agar selalu siap dan mampu menguasai serta menerapkan setiap alternatif inovasi yang dapat digunakan untuk meningkatkan produktivitas usahatani (Mardikanto, 1991). Kegiatan penyuluhan dapat berjalan apabila adanya petani yang mendukung, sehingga tujuan dengan diadakanya penyuluhan tersebut dapat tersampaikan dan terealisasi. Dalam penelitian ini, peneliti ingin mengkaji tentang persepsi petani padi terhadap kegiatan penyuluhan pertanian yang ada di Desa Sukarami Kelurahan Taba Penanjung Kabupaten Bengkulu Tengah. Penelitian ini dilakukan pada Bulan Juni-Juli 2013 di Desa Sukarami Kelurahan Taba Penanjung Kabupaten Bengkulu Tengah. Pengambilan sampel dilakukan dengan Rumus Standar Deviasi yang melibatkan 36 orang responden dari 182 jumlah sampel.Data primer merupakan data yang didapat secara langsung dari responden dengan melakukan wawancara berdasarkan kuisioner yang telah dipersiapkan. Data sekunder diambil dari data sebelumnya seperti dari kantor desa dan instansi lainnya yang berkaitan dengan penelitian ini. Berdasarkan hasil penelitian, maka dapat disimpulkan bahwa persepsi petani terhadap kegiatan penyuluhan pertanian adalah baik karena bisa menambah pengetahuan, keterampilan, motivasi, meningkatkan produktivitas usaha tani.
\end{abstract}

Kata kunci : Persepsi, Petani, Penyuluhan Pertanian

\section{ABSTRACT}

Agricultural development is an important and integral part of national development. It is evident from the self-sufficiency of rice in 1982. The success of agricultural development is inseparable from agricultural extension activities as a social innovation that aims to change the behavior of people (farmers) to always be ready and able to master and apply each alternative innovations that can be used to improve farm productivity (Mardikanto, 1991). Extension activities can be run if the farmer who supports that goal by holding counseling can be delivered and realized. In this study, researchers wanted to examine the perceptions of paddy farmers towards agricultural extension activities in the Sukarami village, Taba 
Penanjung, Middle of Bengkulu Regency. The research was conducted in June - July 2013 in Sukarami village, Taba Penanjung, of Middle Bengkulu regency. Sampling was performed with a standard deviation formula involving 36 people from the 182 sample respondents. Necessary data were taken from two sources namely primary data and secondary data. Primary data is data obtained directly from respondents by conducting interviews based on questionnaires that have been prepared. Secondary data were taken from previous data like from the village office and others agencies associated with this research. Based on the research results, it can be concluded that the perception of farmers on agricultural extension activities are good because it can increase the farmers knowledge, skills, motivation and farm productivity.

Keywords : Perceptions, Farmers, Agricultural Extension.

\section{PENDAHULUAN}

Pertanian di Indonesia merupakan salah satu usaha produksi yang menjanjikan keuntungan. Didukung oleh iklim tropis yang menyediakan sinar matahari dan air yang melimpah, tanaman seharusnya tidak mengalami kendala dalam proses pertumbuhan dan produksinya. Namun kenyataannya yang dihadapi petani Indonesia dari dulu hingga saat ini adalah hasil produksi yang rendah bahkan sering kali tidak mendapatkan hasil apapun akibat gagal panen. Kegagalan dalam usahatani merupakan penyebab utama kemiskinan para petani. Di lain pihak rendahnya produksi dan kegagalan panen memaksa pemerintah membuka pintu impor terhadap produk pertanian dari negara lain termasuk beras, jagung dan buah-buahan yang justru merugikan petani lokal. Sudah sejak lama para ahli pertanian berusaha meningkatkan produksi pertanian. Berbagai riset dan pertemuan terus dilakukan baik oleh lembaga peneliti pemerintah, swasta dan universitas. Walau telah banyak riset yang tlah dilalakukan, namun di lapangan tidak banyak berpengaruh terhadap peningkatan produksi maupun ekonomi petani. Hal ini menunjukkan betapa rumitnya proses produksi dalam bidang pertanian. Di samping usaha-usaha konstruktif meningkatkan hasil produksi, petani harus mampu menanggulangi resiko kerugian yang disebabkan oleh faktor lingkungan dan ekonomi antara lain kekeringan, kebanjiran, hama, penyakit, gulma, harga jual yang tidak pasti, kebutuhan ekonomi keluarga yang terus meningkat (Trieschmann dan Gustavson, 1988). Selain itu kebijakan pemerintah untuk meningkatkan produksi pertanian selama ini lebih terfokus pada pengadaan sarana, prasarana dan teknologi seperti pembuatan irigasi, penyiapan lahan baru, pemberian subsidi terhadap pupuk kimia serta 
pemberian kemudahan dalam aturan pemasaran pestisida.

Pembangunan pertanian merupakan bagian penting dan tidak terpisahkan dari pembangunan nasional. Hal ini terlihat dari swasembada beras pada tahun 1982. Keberhasilan pembangunan pertanian tidak terlepas dari kegiatan penyuluhan pertanian sebagai inovasi-sosial yang bertujuan untuk mengubah tingkah laku masyarakat (petani) agar selalu siap dan mampu menguasai serta menerapkan setiap alternatif inovasi yang dapat digunakan untuk meningkatkan produktivitas usahatani (Mardikanto, 1991).

Proses penyuluhan pertanian dapat diartikan sebagai suatu sistem pendidikan, yang dalam prakteknya juga mempergunakan cara-cara lainnya seperti peniruan, pembujukan dan propaganda. Dalam era reformasi dan otonomi sekarang ini, pendekatan dari atas tentunya sudah tidak relevan lagi, karena yang kita inginkan adalah bahwa petani dan keluarganya mengelola usahataninya dengan penuh kesadaran, bukan terpaksa, maupun melakukan pilihan-pilihan yang tepat dari alternatif yang ada, yang ditawarkan penyuluhan pertanian dan pihak-pihak lain. Dengan pilihannya itu, petani yakin bahwa dia akan dapat mengelola usahataninya dengan produktif, efisien dan menguntungkan serta berdaya saing tinggi. Dalam melakukan pilihan inilah, petani mendapatkan bantuan dari penyuluhan pertanian dan pihak lain yang berkepentingan dalam bentuk hubungan kemitraan, sehingga tidak terjadi pemaksaan (Anonim,2010).

Penyelenggaraan penyuluhan pertanian akan berjalan dengan baik apabila ada persamaan persepsi dan keterpaduan kegiatan antara Pusat, Provinsi dan Kabupaten/kota bahkan sampai ke tingkat Desa dalam satu sistem penyuluhan pertanian yang disepakati bersama dengan melibatkan petani, swasta dan pihak-pihak yang berkepentingan, peranan petani dalam penyuluhan sangat penting karena dengan adanya peranan petani yang mendukung maka kegiatan kegiatan penyuluhan akan terlaksana dengan baik. Akan tetapi kenyataannya sekarang ini masing-masing pihak berjalan sendirisendiri, sehingga penyelenggaraan penyuluhan pertanian menjadi tidak produktif, tidak efisien, dan tidak efektif.

\section{METODE PENELITIAN}

Penelitian ini dilaksanakan pada Bulan Juni - Juli 2013. Penentuan lokasi penelitian ini dilakukan secara sengaja (purposive ) yakni di Desa Sukarami 
Kelurahan Taba Penanjung Kabupaten Bengkulu Tengah. Alasan penulis memilih lokasi penelitian di sini karena cukup banyak petani yang menanam padi di wilayah ini yaitu 182 petani sawah, sehingga tentu saja para penyuluh aktif disini.

Responden dalam penelitian ini adalah petani padi yang menjadi sasaran kegiatan penyuluhan, setelah didata didapat jumlah populasi sebanyak 182 petani padi. Dengan penetapan besarnya responden dalam penelitian ini mengikuti keteraturan Arikunto (1999) yakni apabila subyek kurang dari 100 lebih baik diambil semuanya, sehingga penelitian merupakan penelitian populasi. Selanjutnya apabila jumlah subyek besar atau lebih dari 100 maka diambil antara 10\%-25\% atau lebih tergantung waktu, tenaga dan dana.

Berdasarkan pendapat diatas maka jumlah sampel dalam penelitian ini adalah sebanyak 36 orang atau $20 \%$ dari jumlah populasi, pengambilan sampel dilakukan dengan acak sederhana (simple random sampling). Data yang diperlukan, diambil dari dua sumber yaitu data primer dan data sekunder. Data primer merupakan data yang didapat secara langsung dari responden dengan melakukan wawancara berdasarkan kuisioner yang telah dipersiapkan. Data sekunder diambil dari data sebelumnya seperti dari Dinas Pertanian, kantor desa dan istansi lainnya yang berkaitan dengan penelitian ini.

Analisa data yang digunakan untuk mengetahui persepsi terhadap kegiatan penyuluhan pertanian padi sawah, dilakukan dengan analisis deskriptif. Menurut Nazir dalam Sari (2009), metode deskriptif adalah suatu metode dalam penelitian suatu objek, suatu kelompok manusia, kondisi suatu sistem pemikiran ataupun suatu kelas peristiwa pada masa sekarang dengan tujuan membuat deskriptif gambaran atau lukisan secara sistematis, faktual dan akurat mengenai fakta-fakta, sifat-sifat serta hubungan antara fenomena yang diselidiki. Data-data mengenai karakteristik petani sebagai responden dianalisis secara deskritif dengan menggunakan tabel-tabel distribusi dan persentase. Analisis kualitatif digunakan untuk lebih mendukung dan memperjelas data kuantitatif yang dipaparkan, sehingga antara data kuantitatif dan kualitatif bersifat saling melengkapi. Untuk data rasio (pendidikan formal, luas lahan, jumlah tanggungan keluarga, lamanya berusaha tani) menggunakan perhitungan Standar Deviasi.

Rumus Standar Deviasi : 


$$
\mathrm{Sd}=\sqrt{\frac{1}{\mathrm{n}-1}} I(X i-X)^{2}
$$

Dimana :

Sd : Standar Deviasi

$X$ : Rata-rata Skor

$\mathrm{X} i$ : Jumlah Skor pada responden

$\mathrm{n}$ : Jumlah responden

ketentuan jenjang kategori faktor yang diteliti meliputi :

a. Baik/tinggi, jika $\mathrm{X}>(\mathrm{X}+1 / 2 s d)$

b. Sedang, jika $(\mathrm{X}-1 / 2 s d) \leq \mathrm{X} i \leq(\mathrm{X}+$ $1 / 2 s d)$

c. Jelek/rendah, jika $\mathrm{X} i<(\mathrm{X}+1 / 2 s d)$

Menurut Nazir (1998) untuk mengetahui faktor-faktor yang berhubungan persepsi petani terhadap kegiatan penyuluhan pertanian ini yaitu setuju, kurang setuju/ragu-ragu dan tidak setuju. Total skor dalam pertanyaan merupakan penggabungan dari seluruh jawaban setiap responden.

Untuk memudahkan pengukuran masingmasing item pertanyaan diberi skor, adapun pilihaan dan bobot nilai jawaban untuk persepsi petani padi terhadap kegiatan penyuluhan pertanian di Desa Sukarami Kelurahan Taba Penanjung Kabupaten Bengkulu Tengah :

1. Setuju diberi skor 3

2. Kurang setuju/ragu-ragu diberi skor 2

3. Tidak setuju diberi skor 1

\section{HASIL DAN PEMBAHASAN}

\section{Petani Responden yang Mengikuti}

\section{Kegiatan Penyuluhan.}

Kegiatan penyuluhan berguna untuk diterapkan pada bidang pertanian terutama pada petani padi sawah yang ada di Desa Sukarami, karena masih banyak petani yang perlu dibimbing atau binaan seperti petani padi sawah. Kegiatan yang dilakukan penyuluhan untuk memajukan pertanian adalah memberikan pengetahuan kepada petani tentang bagaimana cara meningkatkan hasil pertanian mereka. Petani yang mengikuti penyuluhan dapat dilihat pada tabel berikut ini

Tabel 1. Petani yang Mengikuti Penyuluhan dalam 1 tahun

\begin{tabular}{|c|c|c|c|}
\hline No & $\begin{array}{l}\text { Frekuensi yang mengikuti } \\
\text { Penyuluhan }\end{array}$ & Jumlah (orang) & Persentase $(\%)$ \\
\hline 1 & Sering (2-3 kali) & 7 & 19,44 \\
\hline 2 & Sekali & 29 & 80,56 \\
\hline & Jumlah & 36 & 100 \\
\hline
\end{tabular}

Petani yang sering mengikuti penyuluhan sebanyak $19,44 . \%$ atau 7 orang, sekali sebanyak 80,56\% atau 29 orang. Artinya petani yang aktif mengikuti kegiatan 
penyuluhan hanya sedikit, sedangkan petani yang mengikuti kegiatan penyuluhan sekali lebih banyak. Persepsi petani yang mengikuti penyuluhan dengan frekuensi sekali adalah 29 orang, ini bukan berarti petani tidak setuju dengan adanya kegiatan penyuluhan pertanian melainkan ada beberapa alasan petani tidak ikut selalu kegiatan penyuluhan yang diadakan antara lain pengaruh bahasa daerah, dimana mayoritas penduduk yang paling dominan adalah suku Rejang, mereka lebih sering menggunakan bahasa daerah sehingga mereka membutuhkan juru bicara, karena juru bicara membantu mereka ketika mengikuti penyuluhan, apabila petani kurang mengerti atau ada yang ingin ditanya mereka dapat berbicara melalui juru bicara.
Peran penyuluh yang masih tergolong muda dianggap petani pengetahuan yang dimiliki belum berpengalaman, cukup baik dan luas dalam penyampaian materi.

\section{Persepsi Petani Terhadap Penyuluhan.}

Persepsi petani dapat diartikan sebagai suatu tanggapan, pemikiran dan pandangan petani terhadap program penyuluhan padi yang ada di Desa Sukarami. Penyuluhan pertanian merupakan salah satu sumber informasi bagi petani dalam meningkatkan produktifitas petani. Kegiatan penyuluhan dapat berjalan apabila adanya petani yang mendukung sehingga tujuan dengan diadakannya penyuluhan tersebut dapat tersampaikan dan terealisasi pada petani di Desa Sukarami. Adapun persepsi petani ini dapat dilihat pada berikut ini :

Tabel 2. Persepsi Petani terhadap Kegiatan Penyuluhan di Desa Sukarami.

\begin{tabular}{clcc}
\hline No & Katagori Persepsi & Jumlah (orang) & Persentase $(\%)$ \\
\hline 1 & Baik $(\geq 30)$ & 23 & 63,89 \\
2 & Sedang $(28-29)$ & 2 & 5,55 \\
3 & Jelek $(<27)$ & 11 & 30,56 \\
& Jumlah & 36 & 100 \\
\hline
\end{tabular}

Sumber : Data Primer Diolah 2013

Berdasarkan Tabel 2 diatas menunjukkan bahwa $63,89 \%$ atau 23 orang petani berpendapat baik terhadap kegiatan penyuluhan yang ada di Desa Sukarami. Menurut petani dengan adanya kegiatan penyuluhan petani dapat menambah pengetahuan, karena pendidikan formal rata-rata petani di Desa Sukarami hanya sebatas Sekolah Dasar, SLTP dan hanya sedikit yang menempuh pendidikan Sekolah Menengah keatas dan dalam pengetahuan usahatani mereka peroleh dari pengalaman turun temurun orang tua mereka dan pengalaman dari petani yang 
ada di sekitar mereka. Sehingga dengan mengikuti kegiatan penyuluhan pengetahuan petani jadi bertambah. Mulai dari cara budidaya tanaman padi yang baik, penggunaan pupuk yang tepat, tata cara penanaman yang baik serta pemilihan dalam menggunakan benih varietas unggul. Dengan begitu produktivitas usahatani diharapkan dapat meningkat. Selain itu dengan adanya penyuluh petani juga dapat berdiskusi atau menghubungi penyuluh ketika petani mendapatkan masalah dalam usahataninya.

Persepsi petani terhadap kegiatan penyuluhan dipengaruhi oleh :

1. Umur.

Menurut Mubyarto (1989) umur petani yang masih tergolong produktif yaitu 46 tahun keatas masih mampu untuk bekerja lebih baik dan tanggap terhadap materimateri yang disampaikan oleh penyuluh dan memiliki kemampuan untuk berusaha memberikan hasil yang maksimal

\section{Pekerjaan}

Pekerjaan utama di desa Sukarami adalah petani. Dengan mengikuti penyuluhan petani dapat menambah pengetahuannya terhadap usahatani yang petani kelola, karena hasil dari pekerjaan itu untuk menafkahi keluarganya.

3. Pengalaman sebagai petani
Hal ini menjelaskan lamanya petani melakukan usahatani padi sawah. Pengalaman dalam berusahatani padi sawah juga menunjukkan besar kecilnya pengetahuan petani terhadap usahatani padi yang diusahakan. Dengan adanya kegiatan penyuluhan petani dapat berbagi dan menambah pengatahuannya terhadap usahatani yang dikelola.

4. Keadaan lahan pertanian

Keadaan lahan daratan yang dimanfaatkan sebagai lahan pertanian untuk persawahan irigasi. Desa Sukarami merupakan salah satu wilayah yang bertopografi daerah daratan sungai sehingga sangat cocok untuk menanam padi karena mempermudah sistem irigasinya. Sehingga dalam penanaman padi tidak mengalami kesulitan dalam perairannya. Dengan mereka punya sistem irigasi yang baik menunjang salah satu bagian kegiatan penyuluhan dalam pengolahan usahatani padi.

Beberapa alasan ketertarikan petani mengikuti kegiatan penyuluhan pertanian :

1. Materi yang disampaikan oleh penyuluh mampu mengatasi masalah pertanian seperti menangani hama, budidaya tanaman padi yang baik, cara penggunaan pupuk yang baik dan benar serta penggunaan bibit varietas unggul. 
2. Penyuluh yang ramah, sabar dan jelas dalam menyampaikan materi tentang budidaya padi sehingga petani mudah untuk memahami dan mempraktekkan di lahan.

3. Adanya sesi tanya jawab untuk petani bertanya kepada penyuluh masalahmasalah yang sedang dihadapi oleh petani, walaupun ada perbedaan bahasa karena petani lebih dominan menggunakan bahasa daerah.

Untuk alasan ketertarikan responden terhadap penyuluhan diperoleh bahwa petani yang berpendapat sedang sebanyak $5,55 \%$ atau 2 orang yang menyatakan bahwa kegiatan penyuluhan kurang setuju dilakukan, karena menurut petani waktu kegiatan penyuluhan sering kali bertepatan dengan kesibukan petani, sehingga petani tidak dapat ikut serta menghadiri kegiatan penyuluhan yang diadakan. Penyuluhan yang disampaikan sebagian tidak dapat diterima sepenuhnya oleh petani, ini karena ada sebagian petani tidak terbiasa menggunakan Bahasa Indonesia tetapi menggunakan bahasa lokal atau daerah mereka. Terkadang materi yang disampaikan tidak sesuai dengan yang dibutuhkan, media dalam penyampaian materi belum tepat, dimana penyuluh kadang menyampaikan materi melalui audio saja atau mulut (suara) tidak memberikan selebaran atau brosur. Sehingga petani tidak cukup lama mengingat materi yang disampaikan. Penyuluh muda dianggap kurang pengetahuan dan dalam penyampaian materi tidak tegas.

Sedangkan petani yang menjawab dengan kategori jelek sebanyak 30,56\% atau 11 orang yang berpendapat bahwa kegiatan penyuluhan tidak perlu dilakukan karena biasanya petani lebih mengerti dan berpengalaman dalam usahatani di bandingkan dengan para penyuluh. Penyuluh juga kurang memahami bahasa yang petani gunakan. Apabila yang melakukan penyuluhan masih tergolong muda, petani di Desa Sukarami menganggap pengetahuan yang dimiliki oleh penyuluh belum berpengalaman, cukup baik dan luas serta dalam penyampaian materi penyuluh tidak tegas dan tepat.

\section{SIMPULAN}

Berdasarkan hasil penelitian, maka dapat disimpulkan bahwa persepsi petani padi terhadap kegiatan penyuluhan di Desa Sukarami Kelurahan Taba Penanjung Kabupaten Bengkulu Tengah adalah baik, menurut mereka dengan diadakannya kegiatan penyuluhan ini maka petani bisa menambah pengetahuan, keterampilan, 
motivasi, meningkatkan produktivitas usaha tani.

\section{SARAN}

Sebaiknya pelaksanaan penyuluhan pertanian yang menggunakan bahasa daerah hendaknya ditambah mengingat masyarakat di Desa Sukarami Dominan menggunakan Bahasa Rejang sehingga ketika mengadakan pertemuan kegiatan penyuluhan pertanian tidak ada kendala dalam penyampaian materi. Dan waktu pelaksanaan kegiatan penyuluhan tidak mengganggu aktivitas petani.

\section{DAFTAR PUSTAKA}

Arikunto. 1999. Metodologi Survey. Dspance.widyatama.ac.id/jspui/ bitsrem/.../bab 3.pdf.

Aryanti. 1995. Konsep Diri dalam Pendidikan. Jakarta : Arcan

Atok, H. 2010. Faktor Yang Mempengaruhi Terbentuknya Persepsi.

http://Miklotof.wordpress.com/2 010/07/30/Faktor-faktor-yangmempengaruhi-terbentuknyapersepsi.

Gibson, Ivancevick dan Donely, 1994. Organisasi. Jilid I. Jakarta. Erlangga.
Gerungan. 1996. Psikologi Sosial. Eresco. Bandung

Hamka. 2002. Hubungan antara Persepsi Terhadap Pengawasan Kerja dengan Motivasi Berprestasi. Skripsi. Surakarta : Universitas Muhammadiyah Fakultas Psikologi. Tidak diterbitkan.

Kartasapoetra, AG. 1994. Teknologi Penyuluhan Pertanian. Bumi Aksara.Jakarta.

Mardikanto. 1991. Penyuluhan Pembangunan Pertanian. Sebelas Maret University Press, Surakarta.

Mubyarto, 1989. Pengantar Ekonomi Pertanian. LP3ES, jakarta

Nazir, M. 1998. Metode Penelitian. Ghalia Indonesia, Jakarta

Sastraatmadja, 1993. Penyuluhan Pertanian. Alumni, Bandung.

Sari, Sp. 2009. Kajian Sumber-sumber Informasi Teknologi Usahatani Padi Sawah Pada Tingkat Petani Kota Bengkulu. Skripsi Jurusan Sosial Ekonomi Pertanian Universitas Bengkulu. (tidak dipublikasikan

Sutarni, S. Mardikanto. 1992. Petunjuk Penyuluhan Pertanian. Usaha Nasional. Surabaya-Indonesia

Tarmizi. 1996. Faktor-Faktor Penghambat Partisipasi Masyarakat Dalam Pembebasan Tanah Bagi Proyek Perkebunan. Skripsi Fisipol Universitas Bengkulu. (tidak dipublikasikan)

Wiriaatmadja. 1986. Pokok-pokok Penyuluhan Pertaanian. CV.Yasaguna. Jakarta 